\title{
Felis catus gammaherpesvirus 1 (FcaGHV1) and coinfections with feline viral pathogens in domestic cats in Brazil
}

\author{
Jacqueline Kazue Kurissio ${ }^{1,2^{*}} \cdot$ Marianna Vaz Rodrigues $^{1,2} \quad$ Sueli Akemi Taniwaki ${ }^{3}$ \\ Marcelo de Souza Zanutto ${ }^{4}$ Claudia Filoni', \\ Maicon Vinícius Galdino ${ }^{5}$ João Pessoa Araújo Júnior ${ }^{1,2^{*}}$
}

\begin{abstract}
'Departamento de Microbiologia e Imunologia, Instituto de Biociências, Faculdade de Medicina Veterinária e Zootecnia (FMVZ), Universidade Estadual Paulista "Júlio de Mesquita Filho" (UNESP), 18618-691, Botucatu, SP, Brasil.

2Instituto de Biotecnologia, Universidade Estadual Paulista “Júlio de Mesquita Filho"(UNESP), Botucatu, SP, Brasil. E-mail: jkkurissio@yahoo.com.br

${ }_{3}^{3}$ Departamento de Medicina Veterinária Preventiva e Saúde Animal, Faculdade de Medicina Veterinária e Zootecnia (FMVZ), Universidade de São Paulo (USP), SP, Brasil.

${ }^{4}$ Departamento de Clínicas Veterinárias, Centro de Ciências Agrárias, Universidade Estadual de Londrina (UEL), Londrina, PR, Brasil.

${ }^{5}$ Departamento de Bioestatística, Instituto de Biociências, Universidade Estadual Paulista “Júlio de Mesquita Filho" (UNESP), 18618-693, Botucatu, SP, Brasil.
\end{abstract}

\begin{abstract}
Felis catus gammaherpesvirus 1 (FcaGHV1) may causes an asymptomatic infection that result in an efficient transmission and subsequently dissemination of the virus in feline population. This study used molecular detection by qPCR (quantitative PCR) based on DNA polymerase gene fragment amplification to evaluate the occurrence of FcaGHV1 and its correlation with other feline viral pathogens, such as Carnivore protoparvovirus 1 (CPPV-1), Felid alphaherpesvirus 1 (FeHV-1), and feline retroviruses such as feline immunodeficiency virus (FIV) and feline lenkemia virus (FeLV). Of the 182 blood samples evaluated 23.6\% (43/182) were positives for FcaGHV1. Approximately $37.9 \%$ (33/87) of the samples that tested positive for retrovirus were also were positive for FcaGHV1 infection $(P<0.0001)$. Among FIVinfected samples, 49\% (24/49) were positive for FcaGHV1 ( $P<0.0001)$. FcaGHV1 infection was not associated with FeLV (P>0.66) or CPPV$1(P>0.46)$ coinfection. All samples were negative for FeHV-1. Male felines were significantly associated to FcaGHV1 $(P<0.0001)$ and their risk of infection with FcaGHVI was about of 7.74 times greater compared to females. Kittens ( $\leq 1$ year) were the least affected by FcaGHVI infection, being verified a rate of $7.7 \%$ (4/52). Therefore, male cats over one year old and infected with FIV were considerably more likely to be infected with FcaGHV1. To our knowledge, this is the first study to report the occurrence and molecular detection of FcaGHVI infection in domestic cats in Brazil and in South America.
\end{abstract}

Key words: gammaherpesvirus, herpesvirus, feline pathogen, infectious diseases, diagnosis.

Ocorrência de Felis catus gammaherpesvirus 1 (FcaGHV1) e coinfecções com patógenos virais felinos em gatos domésticos no Brasil

RESUMO: Felis catus gammaherpesvirus 1 (FcaGHV1) pode causar uma infeção assintomática, que resulta em uma transmissão eficiente e consequente disseminação do virus na população felina. Este estudo utilizou a deteç̧ão molecular por qPCR (PCR quantitativa) baseado na amplificação de um fragmento do gene da DNA polimerase para avaliar a ocorrência de FcaGHV1, sendo correlacionado a outros patógenos virais felinos como Carnivore protoparvovirus 1 (CPPV-1). Felid alphaherpesvirus 1 (FeHV-1) e aos retrovírus felinos como vírus da imunodeficiência felina (FIV) e vírus da leucemia felina (FeLV). Das 182 amostras de sangue avaliadas, 23,6\% (43/182) foram positivas para FcaGHV1. Aproximadamente 37,9\% (33/87) das amostras positivas para retrovirus também foram positivas para FcaGHV1 $(P<0,0001)$. Entre as amostras FIV-infectadas, 49\% (24/49) foram positivas para FcaGHV1 (P<0,0001). A infecção por FcaGHV1 não foi associada à coinfecção por FeLV $(P>0,66)$ e CPPV-1 (P>0,46). Todas as amostras foram negativas para FeHV-1. Felinos machos foram significativativamente associados à infecção por FcaHVI $(P<0,0001)$ e o risco de infecção com $F$ caGHV1 foi aproximadamente 7,74 vezes maior comparados às femeas. Os filhotes ( $\leq 1$ ano) foram os menos acometidos pela infecção por FcaGHVI sendo verificado uma proporção de $7.7 \%$ (4/52). Assim, gatos machos com mais de um ano de idade e infectados por FIV foram, consideravelmente, mais susceptiveis a serem infectados com FcaGHV1. Para nosso conhecimento, este é o primeiro estudo que relata a ocorrência de infecção e detecção molecular de FcaGHVl em gatos domésticos no Brasil e na América do Sul.

Palavras-chave: gamaherpesvirus, herpesvirus, patógenos felinos, doenças infecciosas, diagnóstico.

\section{INTRODUCTION}

Herpesviruses are large and enveloped viruses that have a linear double-stranded DNA genome. They are divided into three distinct subfamilies: alpha-, beta- and gamma herpesvirus (DAVISON, 2010). The majority of members of the Gammaherpesvirinae subfamily are potentially oncogenic (DAVISON et al., 2009). Thus, gamma herpesviruses are associated with the development 
of lymphoproliferative disorders that persist after the viruses became latent in B lymphocytes (BARTON et al., 2011; SPECK \& GANEM, 2010). These viruses can be effectively contained by the immune system of infected healthy individuals who remain asymptomatic (USHERWOOD et al., 2001). However, in immunosuppressed individuals, infection with gammaherpesvirus, either as a sole agent or by coinfection with other viruses, may lead to the development of neoplasms and lymphoproliferative diseases (MEANS et al., 2007; KAYE et al., 2016).

Felis catus gammaherpesvirus 1 (FcaGHV1) was first identified in the United States by TOYER et al (2014) and has since been associated with coinfections, mainly with feline retroviruses (BEATTY et al., 2014; TROYER et al., 2014). Coinfections involving retroviruses and herpesviruses are common and can occur in humans and animals (ISFORT et al., 1992). Synergistic interactions between herpes and retroviruses can favor disease progression producing a long latency period and efficient immune system evasion (EVERMANN et al., 1991). However, the clinical signs and pathogenesis related to FcaGHV1 infection are still not clear (KAYE et al., 2016; STUTZMANRODRIGUEZ et al. 2016).

FcaGHV1 DNA has been detected in cats from countries on most continents including Europe, Oceania, North America and Asia (TROYER et al., 2014; BEATTY et al., 2014; ERTL et al., 2015; TATENO et al., 2017). Until date, no cases of FcaGHV1 infection have been reported in felids in Brazil or elsewhere in South America. Thus, this study investigated the occurrence of FcaGHV1 infection among domestic cats and correlated it with feline retroviruses (feline immunodeficiency virus (FIV) and feline leukemia virus (FeLV)) and with other viral pathogens such as Carnivore protoparvovirus 1 (CPPV-1), previously known as feline panleukopenia virus (FPV), and Feline alphaherpesvirus 1 (FeHV-1). This research also evaluated potential risk factors of domestic cats for FcaGHV1 infection, regarding sex and age.

\section{MATERIALS AND METHODS}

We analyzed EDTA-treated whole blood samples that were taken from 182 domestic cats in Brazil and sent to routine diagnostics services provided by the Laboratory of Molecular Diagnostics in the Department of Microbiology and Immunology of Universidade Estadual Paulista "Júlio de Mesquita Filho", between years 2008 and 2015. Samples were from cats that had infectious disease suspect and were from several localities of the country. DNA was extracted from the blood samples using a commercial kit (GE HealthCare, Buckinghamshire, UK) following the manufacturer's recommendations. Through molecular techniques using qPCR (quantitative PCR), were detected proviral DNA in 87 feline retrovirus-positive DNA samples, while 95 samples were considered negative for the retrovirus. Of those 87 samples retrovirus-positive, 49 were FIV-positive, 32 were FeLV-positive and 6 samples were positive for both FIV and FeLV. All samples were then tested for FcaGHV1, CPPV-1 and FeHV-1. Detection of FIV proviral DNA was performed based on the method of TANIWAKI \& ARAÚJO JR (2011), and the FeLV proviral DNA detection method used primers described by TANDON et al. (2005) using an ABI 7500 Fast thermal cycler (Applied Biosystems, CA, USA). The CPPV-1 VP2 gene and the FeHV1 glycoprotein $\mathrm{B}$ gene were detected based on the methods described by DECARO et al. (2008) and VÖGTLIN et al. (2002), respectively, using an ABI 7300 thermal cycler (Applied Biosystems).

The qPCR assay was used as qualitative method for detecting the presence of FcaGHV1 DNA. To detect FcaGHV1 DNA, specific primers were designed to target the DNA polymerase gene based on the GenBank sequence KF840715, resulting in a product of $174 \mathrm{bp}$ in length. The primer sequences used for FcaGHV1 gene amplification were FcaGHV1-P1 (forward) 5'CCACATTGAAAGGCCCAAGG-3' and FcaGHV1-P2 (reverse) - 5'TGTTGTCTCCAGAT GCTGACG-3'. The qPCR reaction was then prepared with $10 \mu \mathrm{L}$ of GoTaq $^{\circledR}$ qPCR Master Mix (Promega, WI, USA), $0.2 \mu \mathrm{M}$ of each FcaGHV1 primer, $2.5 \%$ of DMSO ( $\geq 99.5 \%), 4 \mu \mathrm{L}$ of extracted DNA and nuclease free water to a total volume of $20 \mu \mathrm{L}$. The thermal cycling conditions were as follows: $95^{\circ} \mathrm{C}$ for $2 \mathrm{~min}$ followed by 40 cycles at $95^{\circ} \mathrm{C}$ for $10 \mathrm{~s}$ and $60^{\circ} \mathrm{C}$ for $30 \mathrm{~s}$ using an ABI 7500 Fast thermal cycler (Applied Biosystems). Samples evaluated were considered positive when they showed a single melting curve peak at a melting temperature $(\mathrm{Tm})$ of approximately $77.20^{\circ} \mathrm{C}( \pm 0.55)$.

During qPCR testing, amplicons of samples considered to be positive for FcaGHV-1 were analyzed on a $1.5 \%$ agarose gel stained with Neotaq Brilliant Plus DNA Stain at $0.5 \mu \mathrm{L} / \mathrm{mL}$ (NeoBio, SP, Brazil) and then visualized under ultraviolet light. Next, amplicons bands were excised from the agarose gel and purified using the Illustra GFX PCR DNA and Gel Band Purification kit (GE HealthCare) per 
the manufacturer's guidelines. Purified DNA were sequenced bidirectionally at the ABI 3500 platform using the BigDye Terminator 3.0 kit (Applied Biosystems). Sequences of target gene amplified by qPCR were analyzed using MEGA 6.0 software and compared to available GenBank sequences through the Basic Local Alignment Search Tool (BLAST) database. Specificity of qPCR used to detect FcaGHV1 DNA was evaluated using DNA and complementary DNA (cDNA) obtained from the Nobivac Feline 1 HCPCh (Intervet Inc., Nebraska, USA) vaccine and the CRFK (Crandell Rees feline kidney) cell line. This vaccine contained live attenuated viruses from FeHV-1 strain 593-J, feline calicivirus (FCV) strain 894-T, CPPV-1 strain Philips Roxane and Chlamydia psittaci strain Baker. Commercial nuclease-free water was used as the negative control (Promega) instead of a nucleic acid sample.

For statistical analysis, chi-square $(\chi 2)$ tests were performed to evaluate the correlation between FcaGHV1 infection and other pathogens. A $95 \%$ confidence interval $(\mathrm{CI})$ was used, and a P-value $<0.05$ was considered statistically significant. Fisher's exact and odds ratio (OR) tests were performed to compare FcaGHV1 frequencies between male and female cats among different age groups. Potential risk factors were analyzed using logistic regression modelling regarding sex (males and female), age range and retrovirus coinfection (FIV and/or FeLV). The data were classified as binomial (1 for positive and 0 for negative for pathogen infection). Statistical analysis was conducted using SAS software (Statistical Analysis Software).

\section{RESULTS AND DISCUSSION}

The qPCR reaction for FcaGHV1 detection was considered specific since it did not show amplification of FeHV-1, CPPV-1, FCV, $C$. psittaci or CRFK cell amplification. Sequences analysis of amplicons obtained from blood samples that were positive for FcaGHV1 revealed 98\% identity with those deposited in the GenBank under number accession KF840715 and KT595939. The frequency of FcaGHV1 among the domestic felines evaluated in this study was $23.6 \%$ (43/182). Approximately $37.9 \%$ (33/87) of the samples in which retrovirus was detected were also positive for FcaGHV1 infection $(\chi 2=22.0604$ with 1 degree of freedom and $\mathrm{P}<0.0001)$. Among FIV-infected cats, $49 \%(24 / 49)$ were coinfected with FcaGHV1 $(\chi 2=$ 36.9916 and $\mathrm{P}<0.0001)$. Frequency of coinfection with FcaGHV1 and FeLV $(15.6 \%, 5 / 32)$ was not statistically significance $\left(\chi^{2}=0.195 ; \quad \mathrm{P}>0.66\right)$. Consistent with observations made by McLUCKIE et al. (2017), infection with FcaGHV1 did not correlate with FeLV coinfecion. Infection with FcaGHV1 was associated to CPPV-1 because of the 11 samples that were positive for CPPV-1 only 9.1\% (1/11) were coinfected with FcaGHV1 $(\mathrm{P}>0.46)$. The proportion of monoinfected cats with FcaGHV1 (without others infections evaluated) was $4.9 \%(9 / 182)$.

According to a logistic regression model, the frequency of FcaGHV1 infection among the blood samples examined in this study correlated significantly with both $\operatorname{sex}\left(\chi^{2}=26.14 ; \mathrm{P}<0.0001\right)$ and $\left(\chi^{2}=16.55 ; \mathrm{P}=0.0009\right)$. The cats' risks for infection with FcaGHV1 according sex and age are presented in table 1 .

The proportion of infection with FcaGHV1 among young, adult and elderly cats was higher than kittens ( $\leq 1$ year), which had the lowest infection rate at $7.7 \%(4 / 52)$. However, the age range most affected was the adult group at $33.3 \%(17 / 51)$. Regression models showed that belonging to the adults age group correlated with risk for infection with FcaGHV1 (OR

Table 1 - Logistic regression analysis of potential risk factors for FcaGHV1 infection associated with sex and age.

\begin{tabular}{|c|c|c|c|c|c|c|}
\hline \multirow[t]{2}{*}{ Risk factor } & \multirow[t]{2}{*}{ Category } & \multirow[t]{2}{*}{ Frequency } & \multirow[t]{2}{*}{ Odds ratio } & \multicolumn{2}{|c|}{ 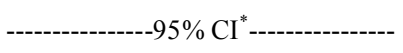 } & \multirow[t]{2}{*}{ P-value } \\
\hline & & & & Lower & Upper & \\
\hline \multirow[t]{3}{*}{ Sex } & Female & $9 \%(8 / 89)$ & Reference & - & - & - \\
\hline & Male & $37.6 \%(35 / 93)$ & 7.74 & 3.2332 & 18.5654 & 0.0001 \\
\hline & Kitten $(\leq 1)$ & $7.7 \%(4 / 52)$ & Reference & - & - & - \\
\hline \multirow[t]{3}{*}{ Age (years) } & Young $(>1$ and $\leq 3)$ & $27.3 \%(12 / 44)$ & 6.94 & 1.9166 & 25.1393 & 0.0190 \\
\hline & Adult $(>3$ and $\leq 10)$ & $33.3 \%(17 / 51)$ & 8.26 & 2.4046 & 28.3948 & 0.0048 \\
\hline & Old $(>10)$ & $28.6 \%(10 / 35)$ & 6.25 & 1.6728 & 23.3524 & 0.0386 \\
\hline
\end{tabular}

${ }^{*}$ Confidence Interval. 
8.26; $\mathrm{P} \leq 0.005$; 95\% CI: 2.4-28.39). The average age of the FcaGHV1-positive cats was 6.25 years.

FcaGHV1 infection was associated significantly with the male sex $(\mathrm{P}<0.0001)$ with a frequency of $37.6 \%(35 / 93 ; \mathrm{P}<0.0001)$ among the male cats. Infection rate among female cats was $9 \%$ $(8 / 89 ; \mathrm{P}=0.427)$, indicating that the occurrence of FcaGHV1-infected males was 4.18 times higher than that among females. Proportion of cats evaluated was $51.1 \%(93 / 182)$ male and 48.9\% (89/182) female; thus no gender bias occurred. We verified that males cats were more likely to be FcaGHV1-infected, with a 7.74 times greater chance when compared to females $(\mathrm{P}=0.0001 ; 95 \% \mathrm{CI}: 3.23-18.56)$. These results were consistent with those of previous studies (BEATTY et al., 2014; ERTL et al., 2015).

The association of males coinfected with FIV and FcaGHV1 was significant $(\mathrm{P}<0.0001)$. Proportion of coinfection with FcaGHV1 and FIV in males was $23.7 \%$ (22/93) and in females, was $2.2 \%$ $(2 / 89)$. Gender distribution of cats that were infected with the viral pathogens tested in this study and those coinfected with FcaGHV1, is presented in figure 1.

Detecting FcaGHV1 DNA with qPCR technique may be useful for specifically and rapidly identifying infected animals (BEATTY et al., 2014). During primary infections with EBV, the circulating EBV DNA levels (in whole blood, plasma, serum, or memory B cells) rise over 2 weeks but may decline for several weeks to months to undetectable levels, then recovering to a steady state (GULLEY \& TANG, 2008). Additionally, FcaGHV1 possibly may establish latency at low-level infection in blood cells (STUTZMAN-RODRIGUEZ et al., 2016). Therefore, presence of gammaherpesvirus DNA in whole blood indicates that are infected individuals (LJUNGMAN et al., 2002). However, a negative qPCR does not necessarily indicate that an animal is not infected, but could instead result from the animal having a viral load too low or with undetectable levels by qPCR (BEATTY et al., 2016; TROYER et al., 2014). Seroprevalence studies suggested that the actual prevalence of FcaGHV1 infection among cats may be higher than those measured using qPCR. For instance, STUZTMAN-RODRIGUES et al. (2016) reported the prevalence of FcaGHV1 infection among cats in the USA to be $32 \%$ when measured with ELISA but only $15 \%$ when measured with qPCR. Studies realized in some countries using qPCR for FcaGHV1 DNA detection were found a prevalence of virus among cats to be $15-19 \%$ in the USA, $11.4 \%$ in Australia, $1.3 \%$ in Japan and $16.2 \%$ in Germany and Austria (TROYER et al., 2014; BEATTY et al.,
2014; ERTL et al., 2015; TATENO et al., 2017). Our study found a frequency of FcaFHV-1 infection among the sample tested to be $23.6 \%$. However, it should be noted that all samples used in this study were samples sent to molecular diagnostic service for feline infectious diseases, instead of taken randomly from an entire population of infected and healthy cats. This may had resulted in a higher frequency rate and the results may not reflect the actual prevalence of FcaGHV1-infected among cats in Brazil. However, it was possible to verify strongly the presence of FcaGHV1 in infected felines.

Male cats, aged over 1 year and coinfected with retroviruses, particularly FIV, were found to be at risk factors for FcaGHV1 infection. Of the positive samples for FIV $(n=49), 49 \%(24 / 49)$ were found positivity for FcaGHV1.This finding is similarly to that of ERTL et al. (2016), who reported that 40.4\% FIV-infected male cats in Europe were coinfected with FcaGHV1. Others studies have verified correlation of FcaGHV1 with FIV infection, as well as the increased FcaGHV1 viral loads related to FIV coinfection (BEATTY et al., 2014; ERTL et al., 2016). Cats with progressive immunodeficiency feline due to viral replication have decreased CD4+ cells and increase of $\mathrm{CD} 8+$, occurring an inverse relationship between CD4+ and CD8+ (PAILLOT et al., 2005; HARTMANN, 2012). The lack of T-cell control induces polyclonal proliferation of B-lymphocytes infected by the gammaherpesvirus, which can persist in the peripheral blood; thus, the frequency of infected cells may be stable for years (BABCOCK et al., 1998; SICA et al., 2009; MARQUES et al., 2012). Therefore, felines coinfected with FcaGHV1 and FIV may present a lytic infection by gammaherpesvirus, allowing the detection viral DNA at this stage (BEATTY et al., 2014). Additionally, territorial, exploratory and aggressive behaviors by male cats increase their risks of virus exposure, as has been observed with FIV infection (NORRIS et al., 2007; DUNHAM \& GRAHAM, 2008). Therefore, horizontal transmission should be evaluated as a possible main route of viral spreading (BEATTY et al., 2014). A previous study found high viral loads in small intestinal tissue of infected cats, and viral excretion in the saliva of FcaGHV1 is suspected as a likely transmission route (BEATTY et al., 2014; TROYER et al., 2014). This is similar to EBV, in which the primary infection is transmitted via saliva and cases of gastroenteritis with EBV have been reported (COHEN, 2000; SICA et al., 2009; FUGIWARA et al., 2009). In contrast, the low occurrence of FcaGHV1 verified in kittens $(7.7 \% ; 4 / 52)$ and female cats $(9 \%$; 


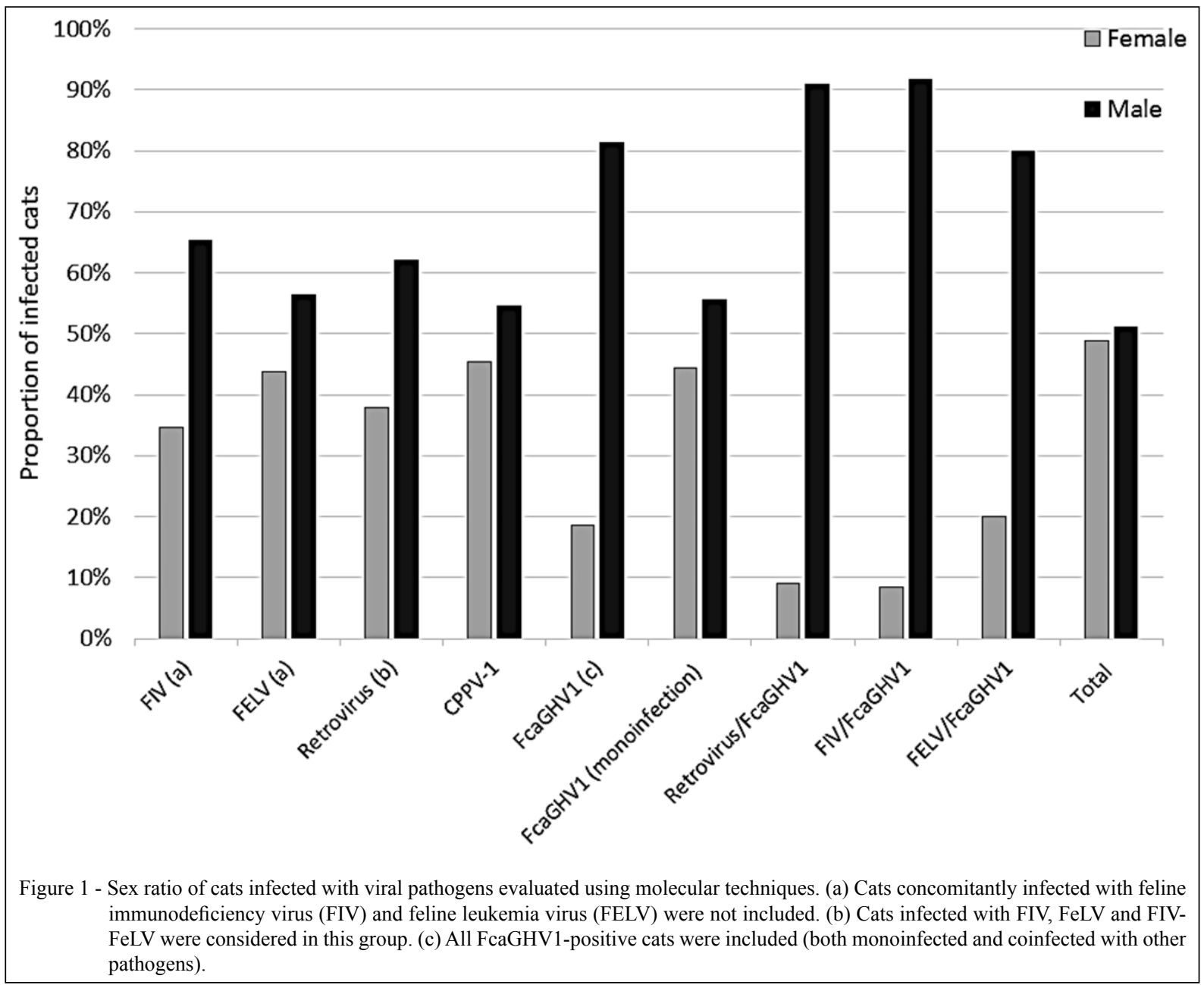

8/89), may indicate that vertical transmission has little implication in the spread of the virus, such as was verified in seroprevalence study by STUTZMANRODRIGUES, 2016.

All blood samples tested during this study were negative for FeHV-1. The prevalence of FeHV1 can vary according to population density of cats, reaching rates lower than 1\% (GASKELL et al., 2007). Some studies suggested that FeHV-1 might be act as cofactor in the pathogenesis of FIV infection and coinfections with both virus may occur naturally (REUBEL et al., 1994; KAWAGUSHI \& MIKAMI, 1995; ONGRÁDI et al., 2013). However, this association was not observed among cats in this study.

Using qPCR, BEATTY et al. (2014) reported higher viral loads of FcaGHV1 in bone marrow. Detection of the virus in the bone marrow suggested that FcaGHV1 might contribute to bone marrow failure, as has been observed in gammaherpesvirus infections (BARANSKI et al., 1988; HART et al., 2008). Therefore, FcaGHV1 infection may potentially compromise bone marrow function as well as FeLV and CPPV-1 (SHIMODA et al., 2000; HARTMANN, 2012). Although, all of them are feline lymphotropic viruses, CPPV-1 and FeLV are T-lymphotropic and FcaGHV1 has tropism for B-lymphocyte (THOMPKINS et al., 1991; IKEDA et al. 1998; McLUCKIE et al., 2016). Unlike for FIV and FcaGHV1, the results of this study do not suggested a correlation among infections with among FeLV, CPPV-1 or FcaGHV1 infection.

Herpesvirus can remain latent throughout the lives of their hosts, which remain exposed at risk for viral reactivation and subsequent disease (BARTON et al., 2007). Moreover, host reservoirs can transmit the virus without evident signals of the disease and virus excretion usually occurs at low levels constantly or intermittently (ACKERMANN, 2006; SPECK

Ciência Rural, v.48, n.3, 2018. 
\& GANEM, 2010). Therefore, FcaGHV1-positive animals can be considered as potential reservoirs of the virus and sources of infection. Thus, diagnosis of FcaGHV1-infected cats may have a role in the control of virus dissemination and allow evaluating the possible effects of the infection on the animal.

\section{CONCLUSION}

To our knowledge, this is the first study to report presence and molecular detection of FcaGHV1 in domestic cats in Brazil and South America, and thereby confirm that this virus is widely distributed throughout the world. Additionally, the results of this study suggested that males cats that are infected with FIV and more than one year old are at higher risk of becoming infected with FcaGHV1 and thus should be investigated.

\section{ACKNOWLEDGMENTS}

This research was funded by the Coordenação de Aperfeiçoamento de Pessoal de Nível Superior (CAPES) and the Fundação do Instituto de Biociências (FUNDIBIO).

\section{REFERENCES}

ACKERMANN, M. Pathogenesis of gammaherpesvirus infections. Veterinary Microbiology, v.113, p.211-222, 2006. Available from: $\quad<$ http://www.scciencedirect.com/science/article/pii/ S037811350500369X>. Accessed: Nov. 09, 2016. doi:10.1016/j. vetmic.2005.11.008.

BABCOCK, G.J. et al. EBV persistence in memory B cells in vivo. Immunity, v.9, n.3, p.395-404, 1998. Available from: <http:// www.cell.com/immunity/fulltext/S1074-7613 (00) 80622-6>. Accessed: Sept. 20, 2016. doi: 10.1016/S1074-7613 (00) 80622-6.

BARANSKI, B. et al. Epstein-Barr virus in the bone marrow of patients with aplastic anemia. Annals of International Medicine, v.109, n.9, p. 695-704, 1988. Available from: <https://www.ncbi. nlm.nih.gov/pubmed/2847613>. Accessed: Sept. 20, 2017. doi: 10.7326/00 03-4819-109-9-695.

BARTON, E. et al. Pathogenesis and host control of gammaherpesviruses: lessons from the mouse. Annual Review of Immunology, v.29, p.351-397, 2011. Available from: $<$ http://www.annualreviews.org/doi/abs/10.1146/annurevimmunol-072710-081639>. Accessed: Nov. 07, 2016. doi: 10.1146/annurev-immunol-072710-081639.

BEATTY, J.A. et al. Felis catus gammaherpesvirus 1; a widely endemic potential pathogen of domestic cats. Virology, v.460461, p.100-107, 2014. Available from: <http://www.sciencedirect. com/science/article/pii/S0042682214002177>. Accessed: Nov. 07, 2016. doi: 10.1016/j.virol.2014.05.007.

COHEN, J. Epstein-Barrvirus infection. The New England Journal of Medicine, v. 343, n.7, p.481-492, 2000. Available from: <http:// www.nejm.org/doi/full/10.1056/NEJM200008173430707>. Accessed: Nov. 06, 2016. doi: 10.1056/NEJM200008173430707.
DAVISON, A. J. et al. The Order Herpesvirales. Archives of Virology, v. 154, n.1, p.171-177, 2009. Available from: <https:// www.ncbi.nlm.nih.gov/pmc/articles/PMC3552636/>. Accessed: Sept. 21, 2016. doi: 10.1007/s00705-008-0278-4.

DAVISON, A. J. Herpesvirus systematics. Veterinary Microbiology, v.143, n.1-2, p.52-69, 2010. Available from: $<$ https://www.ncbi.nlm.nih.gov/pmc/articles/PMC2995426/>. Accessed: Sept. 21, 2016. doi: 10.1016/j.vetmic.2010.02.014.

DECARO, N. et al. Genetic analysis of feline panleukopenia viruses from cats with gastroenteritis. Journal of General Virology, v.89, n.9, p.2290-2298, 2008. Available from: <http:// jgv.microbiologyresearch.org/content/journal/jgv/10.1099/ vir.0.2008/001503-0\#tab2>. Accessed: Mar. 10, 2017. doi: 10.1099/vir.0.2008/001503-0.

DUNHAM, S.P.; GRAHAM, E. Retroviral infections of small animals. Veterinary Clinics of North America: Small Animal Practice, v.38, p.879-901, 2008. Available from: $<$ https://www.sciencedirect.com/science/article/pii/ S0195561608000788>. Accessed: Sept. 25, 2016. doi: 10.1016/j.cvsm.2008.03.005.

ERTL, R. et al. Prevalence and risk factors of gammaherpesvirus infection in domestic cats in Central Europe. Virology Journal, v.12, n.1, p.146, 2015. Available from: <https://virologyj. biomedcentral.com/articles/10.1186/s12985-015-0381-6>. Accessed: Feb. 26, 2107. doi: 10.1186/s12985-015-0381-6.

EVERMANN, J. F. et al. Interactions between herpesviruses and retroviruses: Implications in the initiation of disease. Microbial Pathogenesis, v.10, p.1-9, 1991. Available from: <http://www. sciencedirect.com/science/article/pii/088240109190060N $>$. Accessed: Sept. 09, 2016. doi: 10.1016/0882-4010(91)90060-N.

FUGIWARA, M. et al. Acute Epstein-Barr virus infection presenting as severe gastroenteritis without infectious mononucleosis-like manifestations. Clinical Journal of Gastroenterology, v.2, n. 6, p. 398-403, 2009. Available from: <https://link.springer.com / article/10.1007/s12328-009-0114-8>. Accessed: May 22, 2017. doi: $10.1007 / \mathrm{s} 12328-009-0114-8$.

GASKELL, R. Feline herpesvirus. Veterinary Research, v.38, p. 337-354, 2007. Available from: <https://www.vetres.org/articles/ vetres/abs/2007/02/v07073/v07073.html>. Accessed: May 20, 2017. doi: $10.1051 /$ vetres:2006063.

GULLEY, M. L.; TANG, W. Laboratory assays for Epstein-Barr virus-related disease. Journal of Molecular Diagnostics: JMD, n. 10, v. 4, p. 279-292, 2008. Available from: <https://www.ncbi.nlm. nih.gov/pmc/articles/PMC2438195/>. Accessed: Oct. 02, 2017. doi: 102353/jmoldx.2008.080023.

HART, K.A. et al. Multinodular pulmonary fibrosis, pancytopenia and equine herpesvirus-5 infection in a thoroughbred gelding. Equine Veterinary Education, v. 20, p. 470476, 2008. Available from: <http://onlinelibrary.wiley.com/ doi/10.2746/095777308X334257/>. Accessed: Sept. 09, 2017. doi: $10.2746 / 095777308 X 334257$.

HARTMANN, K. Clinical aspects of feline retroviruses: a review. Viruses, v.4, n.11, p. 2684-2710, 2012. Available from: <https:// www.ncbi.nlm.nih.gov/pmc/ articles /PMC3509 668/>. Accessed: May 30, 2017. doi: 10.3390/v4112684. 
IKEDA, Y. et al. Apoptosis in feline panleukopenia virus-infected lymphocytes. Journal of Virology, v. 72, n.8, p.6932-6936, 1998 Available from: <http://jvi.asm.org/content/72/8/6932.full $>$. Accessed: Jun. 15, 2017. doi: 0022-538X/98/\$04.0010.

ISFORT, R. et al. Retrovirus insertion into herpesvirus in vitro and in vivo. Proceedings of the National Academy of Sciences of the United States of America (PNAS), v.89, p.991-995, 1992. Available from: <https:/www.ncbi.nlm.nih.gov/pmc/articles/ PMC48371/>. Accessed: Nov. 06, 2016. PMCID: PMC48371.

KAYE, S. et al. Role of Feline Immunodeficiency Virus in lymphomagenesis - going alone or colluding? Institute for Laboratory Animal Research Journal, v.57, n.1, p. 24-33, 2016. Available from: $<$ https://academic.oup.com/ilarjournal/article/57/1/24/2363527>. Accessed: Sept. 13, 2017. doi: 10.1093/ilar/ilv047.

KAWAGUSHI, Y.; MIKAMI, T. Molecular interaction between Retrovirus and Herpesvirus. Journal of Veterinary Medical Science, v. 57, 5, 801-811, 1995. Available from: $<$ https://www. jstage.jst.go.jp/article/jvms 1991/57/5/57_5_801/_article $>$. Accessed: Sept. 22, 2016. doi: 10.1292/jvms.57.801.

LJUNGMAN, P.et al. Definitions of cytomegalovirus infection and disease in transplant recipients. Clinical Infectious Diseases, v. 34, 1094-1097, 2002. Available from: <https://academic.oup com/cid/article/34/8/1094/283348 > . Accessed: Mar. 12, 2017. doi: $10.1086 / 339329$.

MARQUES, H. et al. Detection of the Epstein-Barr virus in blood and bone marrow mononuclear cells of patients with aggressive B-cell non-Hodgkin's lymphoma is not associated with prognosis. Oncology Letters, v.4, n. 6, 1285-1289, 2012. Available from: $<$ https://www.ncbi.nlm.nih.gov/pmc/articles/PMC3506762/>. Accessed: May 15, 2017. doi: 10.3892/ol.2012.913.

McLUCKIE, A.J. et al. Felis catus Gammaherpesvirus 1 DNAemia in Whole Blood from Therapeutically Immunosuppressed or RetrovirusInfected Cats. Veterinary Science, v.4, n.1, 16, 2017. Available from: $<$ https:/www.ncbi.nlm.nih.gov/pmc/articles/pmid/29056675/>. Accessed: Sept.27, 2017. doi: 10.3390/vetsci4010016.

MEANS, R.E. et al. Human gammaherpesvirus immune evasions strategies. In: _ Human Herpesvirus: Biology, Therapy and Immunoprophylaxis. Cambridge University Press, 2007. Cap. 31. Available from: <https://www.ncbi.nlm. nih.gov/books/ NBK47420>. Accessed: Mar. 15, 2017.

NORRIS, J. M. et al. Prevalence of feline immunodeficiency virus infection in domesticated and feral cats in eastern Australia. Journal of Feline Medicine and Surgery, v.9,n.4,p. 300-308, 2007. Available from: $<$ http://journals.sagepub.com/doi/abs/10.1016/j.jfms.2007.01.007>. Accessed: Jun. 10, 2017. doi: 10.1016/j.jfms.2007.01.007.

ONGRÁDI, J. et al. Interaction of FIV with Heterologous Microbes in the Feline AIDS Model. Additional information is available at the end of the chapter. 2013. Available from: https://www.intechopen.com books/current-perspectives-in-hiv-infection/interaction-of-fiv-withheterologous-microbes-in-the-feline-aids-model $>$. Accessed: Jun. 20, 2017. doi: $10.5772 / 52767$.

PAILLOT, R. et al. Toward a detailed characterization of feline immunodeficiency virus-specific $\mathrm{T}$ cell immune responses and mediated immune disorders. Veterinary Immunology and Immunopathology, v.106, n.1-2, p.1-14, 2005. Available from: $<$ https://www.sciencedirect com/science/article/pii/S0165242705000024>. Accessed: May 05,
2017. doi: 10.1016/j.vetimm.2004.12.023.

REUBEL, G. $\mathrm{H}$. et al. Effects of incidental infection and immune activation on disease progression in experimental feline immunodeficiency virus infected cats. Journal of Acquired Immune Deficiency Syndromes, v.7, p. 1003-1015, 1994. Available from: $<$ https://journals.lww.com/jaids/Abstract/1994/10000/Effects_of Incidental_Infections_and_Immune.2.aspx>. Accessed: Sept. 27, 2017.

SHIMODA, T.et al. A hematological study on thirteen cats with myelodysplastic syndrome. Journal of Veterinary Medicine Science, v.62, n.1, p.59-64, 2000. Available from: <https://www. jstage.jst.go.jp/article/jvms/62/1/62_1_59/_article>. Accessed: Oct. 09, 2017. doi: 10.1292/jvms.62.59.

SICA, S. et al. Epstein-Barr virus related lymphoproliferations after stem Cell transplantation. Mediterranean Journal of Hematology and Infectious Diseases, v.1, n.2, 2009. Available from: <https:// www.ncbi.nlm.nih.gov/pmc/articles/PMC3033172/>. Accessed: Oct. 02, 2017. doi: 10.4084/MJHID.2009.019.

SPECK, S.H.; GANEM, D. Viral latency and its regulation: lessons from the gammaherpesvirus. Cell Host \& Microbe, v.8, n.1, p.100-115, 2010. Available from: <https://www.ncbi.nlm.nih. gov/pmc/articles/PMC2914632/>. Accessed: Sept. 12, 2017. doi: 10.1 016/j.chom.2010.06.014.

TANDON, R. et al. Quantitation of feline leukaemia virus viral and proviral loads by $\operatorname{TaqMan}^{\circledR}$ real-time polymerase chain reaction. Journal of Virological Methods, v. 40, p.124-132, 2005. Available from: $<$ https:// www.sciencedirect.com/science/article/pii/S0166093405002120>. Accessed: Jun. 01, 2017. doi: 10.1016/j.jviromet.2005.06.017.

TANIWAKI, S.A.; ARAÚJO JR, J.P. Serological or molecular diagnosis of FIV infection: advantages and disadvantages. Journal of the Brazilian Society for Virology - Annals of XXII National Meeting of Virology \& VI Mercosur Meeting of Virology, v.16, p.32-33, 2011.

TATENO, M. et al. Molecular epidemiological study of gammaherpesvirus in domestic cats in Japan. Journal of Veterinary Medical Science, v. 79, n.10, p. 1735-1740, 2017. Available from: $<$ https://www.ncbi.nlm.nih.gov/pmc/articles/PMC5658569/>. Accessed: Oct. 04, 2017. doi: 10.1292/jvms.17-0039.

THOMPKINS, M.B. et al. Early events in the immunopathogenesis of feline retrovirus infections. Journal of the American Veterinary Medical Association, v.199, n.10, p.1311-1315, 1991. Available from: <https://www.ncbi.nlm.nih.gov/pubmed/1666073>. Accessed: Jan. 26, 2018.

TROYER, R. M. et al. Novel Gammaherpesvirus in North American cats Bobcats, and Pumas: Identification, Prevalence, and Risk Factors. Journal of Virology, v.88, n.8, p. 3914-3924, 2014. Available from: <https://www.ncbi.nlm.nih.gov/pmc/articles/PMC3993758/>. Accessed: Sept. 15, 2017. doi: 10.1128/JVI.03405-13.

USHERWOOD, E.J. et al. Latent antigen vaccination in a model gammaherpesvirus infection. Journal of Virology, v.75, n.17, p.8283-8288, 2011. Available from: <https://www.ncbi.nlm.nih. gov/pmc/articles/PMC115072/>. Accessed: Feb. 26, 2017. doi: 10.1128/JVI.75.17.8283-8288.2001.

VÖGTLIN, A. et al. Quantification of Feline Herpesvirus 1 DNA in Ocular Fluid Samples of Clinically Diseased Cats by Real-Time TaqMan PCR. Journal of Clinical Microbiology, v.40, p.519-52, 2002. Available from: < https://www.ncbi.nlm.nih.gov/pmc/articles/PMC153372/>. Accessed: Jun. 01, 2017. doi: 10.1128/JCM.40.2.519-523.2002. 